\title{
Large fungating squamous cell carcinoma of the penis
}

\author{
Deirdre Mary Fanning, James Forde, Kevin O'Connor, Ted Mc Dermott
}

Urology Department, St James's Hospital, Dublin, Ireland

Correspondence to Miss Deirdre Mary Fanning, fanningdee@yahoo.co.uk

\section{DESCRIPTION}

A man presented with a 1-year history of a progressively worsening penile skin lesion. Over the preceding 2 months, he reported passage of urine from two distinct exit points on the distal penis. There were associated low grade penile pain, dysuria, spraying of urine on micturition, daytime urinary frequency, nocturia of three, the sensation of incomplete bladder emptying and contact bleeding at the distal penis. On presentation, there was a $6 \mathrm{~cm}$ circumferential fungating lesion on the distal penis. There was evidence of superficial spreading. The lesion extended $8 \mathrm{~cm}$ proximally. There was evidence of ulceration and contact bleeding. It was not possible to identify the external urethral meatus (figures 1 and 2). There was no associated inguinal lymphadenopathy. Biopsy showed invasive, well differentiated squamous cell carcinoma. An inguinal ultrasound was negative for lymphadenopathy. A staging CT scan of the thorax, abdomen and pelvis showed no evidence of metastatic disease. A total penectomy and formation of a perineal urethrostomy was performed

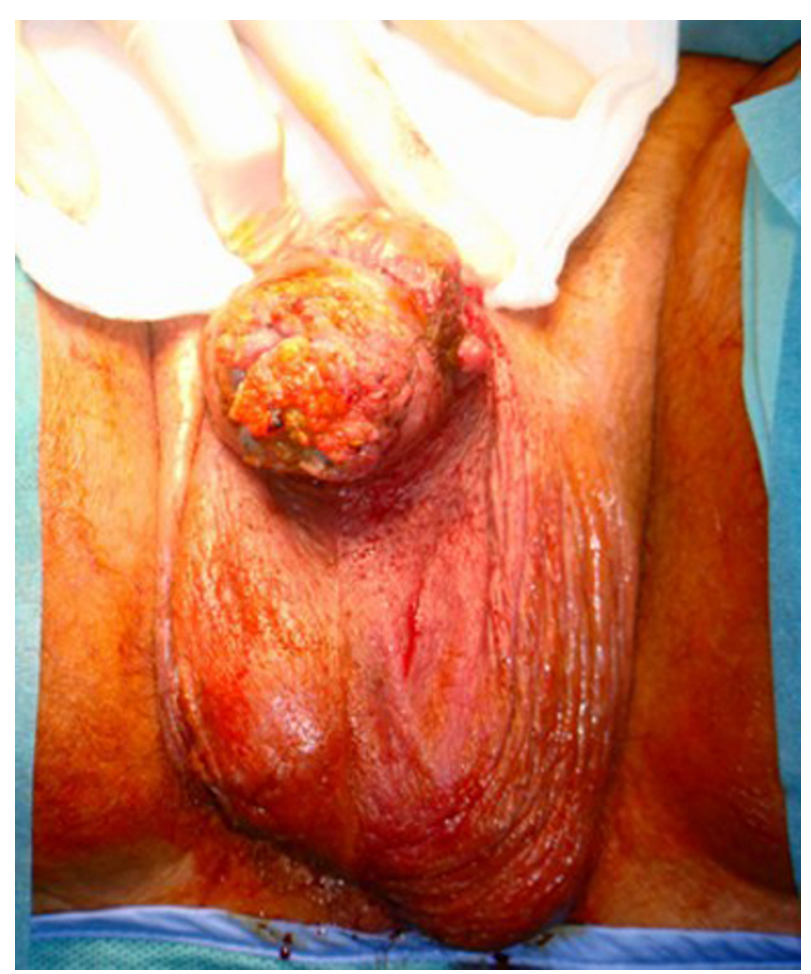

Figure 1 Preoperative anterior view of the fungating penile lesion. (figures 3-5). The pathological specimen showed an invasive, well differentiated squamous cell carcinoma. The tumour measured $9 \mathrm{~cm}$ in length and $6 \mathrm{~cm}$ in diameter. The carcinoma invaded into the subepithelial connective tissue and the underlying corpus cavernosa. There was no evidence of vascular or urethral invasion. The proximal resection margins were free of tumour. The

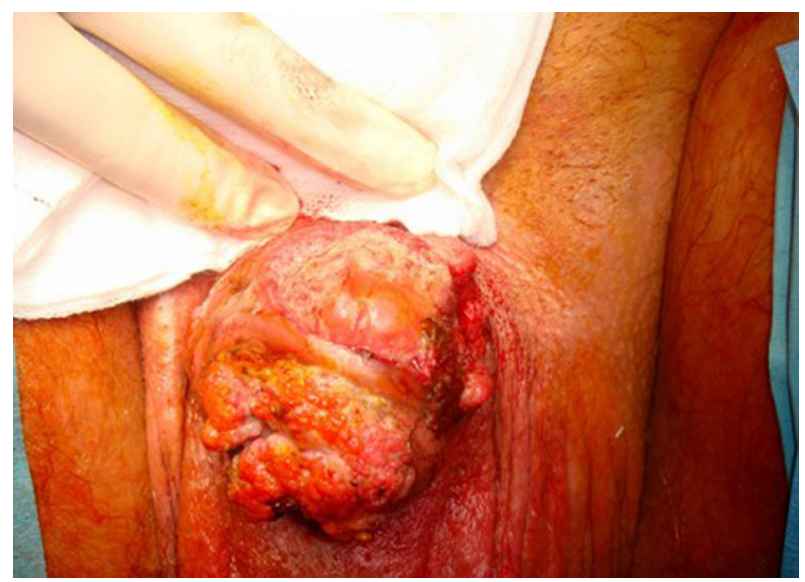

Figure 2 Preoperative anterosuperior view of the fungating penile lesion.

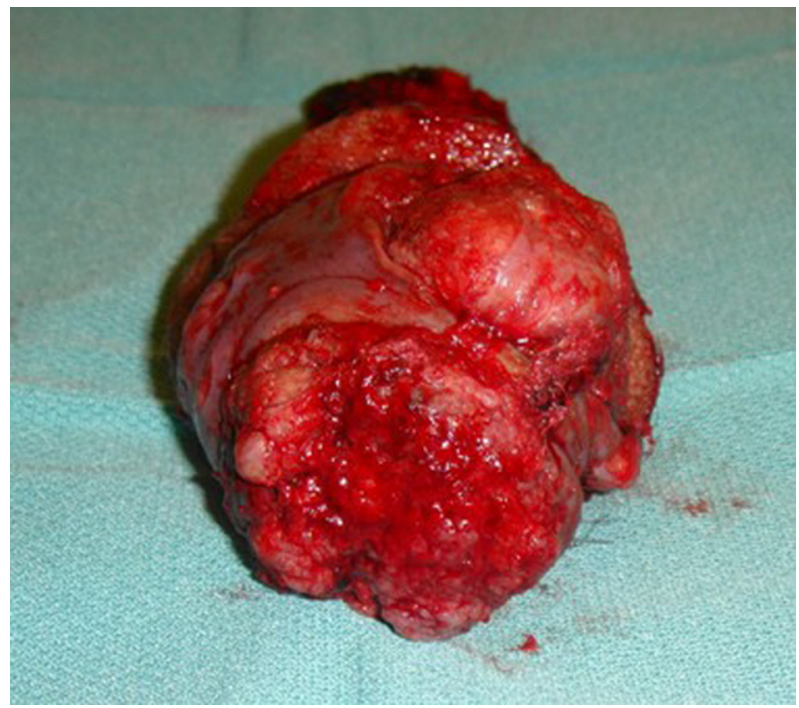

Figure 3 Anterosuperior view of the resected penile lesion. The specimen measured $16 \mathrm{~cm}$ in length with a diameter of $6.5 \mathrm{~cm}$ and $19 \mathrm{~cm}$ circumference. 


\section{BMJ Case Reports}

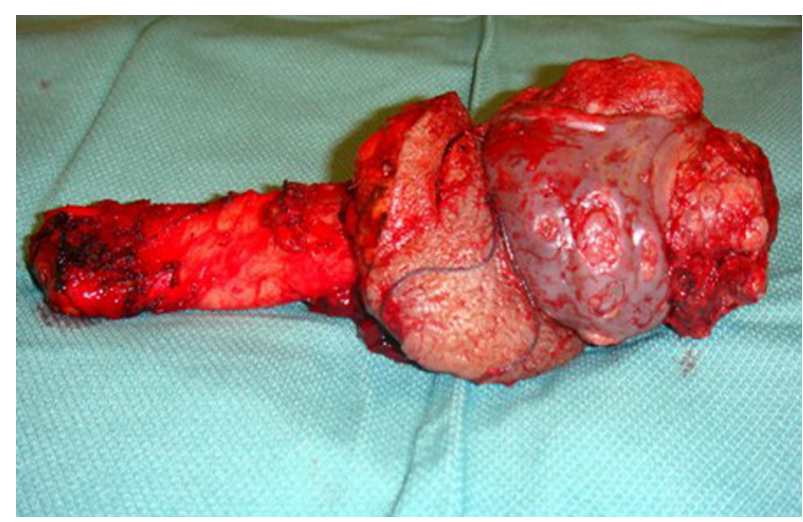

Figure 4 Lateral view of the total penectomy specimen.

specimen was classified as pT2 N0 M0. The patient made an uneventful recovery. Routine follow-up is scheduled at 6 months intervals for the first 2 years, and yearly thereafter to 2 years. It shall consist of a thorough physical examination.

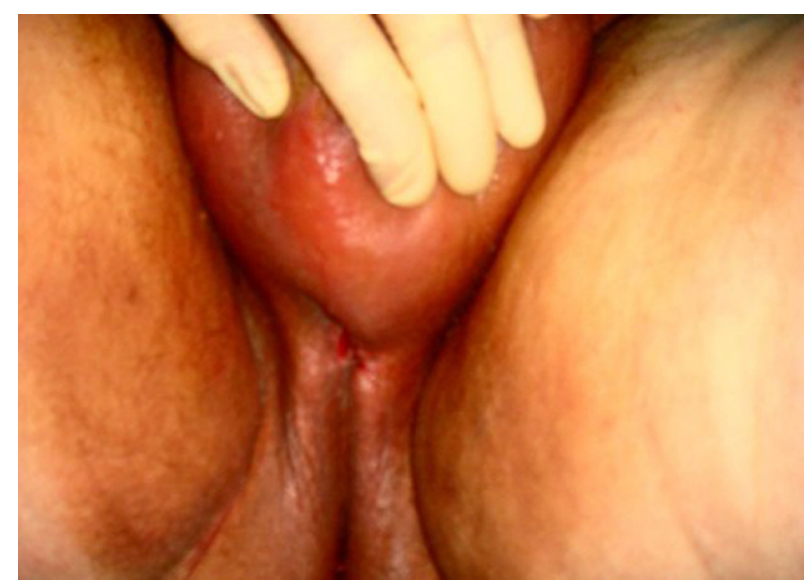

Figure 5 Anterior view of the perineal urethrostomy at day 7 post-total penectomy.

Competing interests None.

Patient consent Obtained.

This pdf has been created automatically from the final edited text and images.

Copyright 2011 BMJ Publishing Group. All rights reserved. For permission to reuse any of this content visit http://group.bmj.com/group/rights-licensing/permissions.

BMJ Case Report Fellows may re-use this article for personal use and teaching without any further permission.

Please cite this article as follows (you will need to access the article online to obtain the date of publication).

Fanning DM, Forde J, O'Connor K, Mc Dermott T. Large fungating squamous cell carcinoma of the penis. BMJ Case Reports 2011; 10.1136/bcr.05.2011.4179, date of publication

Become a Fellow of BMJ Case Reports today and you can:

- Submit as many cases as you like

- Enjoy fast sympathetic peer review and rapid publication of accepted articles

- Access all the published articles

- Re-use any of the published material for personal use and teaching without further permission

For information on Institutional Fellowships contact consortiasales@bmjgroup.com

Visit casereports.bmj.com for more articles like this and to become a Fellow 